\title{
Współczesna powieść kryminalna jako wariacja na temat superbohatera. Rozważania wstępne
}

\section{Bernadetta Darska}

Mówienie o powieści kryminalnej w kontekście historii o superbohaterach tylko pozornie wydawać się może czymś nieszczególnie trafnym. Odwołanie do odmiennych rejestrów, w których funkcjonuje superbohater, okazuje się bowiem tylko umownym przyporządkowaniem. Biografia tego typu postaci ma w sobie uniwersalne przesłanie, które jest spójne z tym, co konstytuuje definicję bohatera kryminału. W tym najprostszym rozumieniu i detektyw, i superbohater walczą ze złem i reprezentują dobro. Mają jednak dużo więcej cech wspólnych, co w dalszej części artykułu postaram się udowodnić. Detektyw kojarzony z powieścią kryminalną funkcjonuje w przestrzeni literatury, a więc słowa. Superbohater powiązany z publikacjami komiksowymi przywodzi na myśl głównie obrazy. To, co w kryminale dzieje się za pomocą pojawiania się kolejnych zdań, w komiksie rozgrywane jest za pomocą rysunku. Akcja rozwija się dzięki ujawnianiu następujących po sobie wydarzeń - w powieści obrazy generowane są przez pracę wyobraźni, w komiksie uzupełnieniem sfery wizualnej są słowa ${ }^{1}$.

W obu przypadkach kwestie nadmiaru, niedopowiedzenia i dosłowności okazują się niezwykle istotne. Dla powieści kryminalnej szczególnie niekorzystny wydaje się nadmiar. To, co potocznie, nazywamy przegadaniem, wpływa zwykle na jakość tekstu literackiego i pozwala na ocenę pisarskiej sprawności autora. W komiksie również bardzo ważne jest nienadużywanie słów. Choć mowa w tym wypadku przede wszystkim o krótkich dialogach, to jednak gdy wypowiedzi bohaterów stają się za długie, świadczy to zwykle o słabości rysownika, który w ten sposób obnaża swoje braki warsztatowe. W komiksie najwięcej dzieje się dzięki temu, co widzimy, a nie czytamy. W powieści kryminalnej odwrotnie - to, co zostało napisane, umożliwia nam wyobrażenie sobie tego wszystkiego, co opisuje autor. Kluczowe dla budowania napięcia w powieści o zbrodni jest niedopowiedzenie. Komiks również bazuje na zniuansowaniu wynikającym z braku dosłowności. Rysunek umożliwia zwielokrotnienie sensów i znosi jednoznaczność potencjalnego odbioru. Literatura gatunkowa opiera się na schematach fabularnych i związanych z konstruowaniem postaci. Nie inaczej jest w przypadku komiksu superbohaterskiego. Receptą na wydawniczy i czytelniczy sukces bywa więc często zasada złotego środa - wierność gatunkowym regułom przy jednoczesnej gotowości ich renegocjowania.

\footnotetext{
${ }^{1}$ Bartosz Kurc akcentuje: „Podstawowym składnikiem komiksu jest obraz i słowo, połączone ze sobą nierozdzielnie. Ocenianie jednej z jego nierozdzielnych cech bez zauważania drugiej jest błędem”. B. Kurc, Komiks - opowiadanie obrazem. Od narracji do znaku, Koluszki 2016, s. 47.
} 
Nie bez znaczenia dla tytułowego rozpoznania sugerującego związek między powieścią kryminalną a fabułą superbohaterską jest zniesienie różnicy wynikającej z korzystania z innych sposobów obrazowania oraz zatrzymanie się przy ustaleniu, iż nie tylko detektyw jest marką dla kryminału, ale i superbohater staje się marką dla komiksu. Wojciech Burszta i Mariusz Czubaj w Krwawej setce nie pozostawiają złudzeń: „Cechą dobrego kryminału jest i to - jak w żadnej innej bodaj odmianie literatury - że wykreowani w nim bohaterowie zapadają w pamięć. Ba, można wręcz powiedzieć, że dobry kryminał bez wyrazistych postaci nie istnieje"2. Warto w tym kontekście pamiętać o możliwym poszerzeniu rejestru odbiorców związanym z ewentualną ekranizacją powieści kryminalnych oraz komiksów. W obu przypadkach ma miejsce istotnie efekt promocyjny - ci, którzy już są fanami, zwykle chcą poznać efekt pracy filmowców, ci, którzy jeszcze nimi nie zostali, z racji popularności danej fikcyjnej postaci chętnie idą do kin lub siadają przed telewizorami/monitorami laptopów, żeby obejrzeć film lub serial, ci, którzy nie zdecydują się na oglądanie, często również nie są obojętni, bo machina promocyjna jest tak duża, że część informacji wymagających ustosunkowania się do odbiorcy dociera także i do nich ${ }^{3}$. W efekcie możliwość multiplikowania treści wpisana w kulturę popularną prowadzi do międzygatunkowego spotkania, którego podstawą jest podobna idea porządkująca czyny bohaterów, zgoda na podobne opisywanie świata, wreszcie tkwiące w danej historii przesłanie, że zło przynajmniej na chwilę da się zwyciężyć. Doskonałym przykładem nie tylko podobnych działań w przestrzeni kryminału i komiksu, ale i dosłownego połączenia cech obu gatunku są kolejne części z Jamesem Bondem w roli głównej. Mamy więc powieści, dużo bardziej rozsławiające bohatera i jego pomysłodawcę Iana Fleminga filmy, serię komiksową, ciągle rozwijającą się produkcję gadżetów poświęconych postaci agenta 007. Wszystko to odsłania nie tylko fenomen zaistnienia sojuszu na poziomie wykorzystania Bonda jako inspiracji dla różnych gatunków i różnych działań reklamowych. Umożliwia również dostrzeżenie takiego skonstruowania postaci, że na plan pierwszy wysuwa się jej związek z powieścią kryminalną i komiksem superbohaterskim jednocześnie. Ta dwoistość, dzięki której możliwe jest szerokie i dość jednoznaczne utożsamienie się, wpływa na popularność Bonda. Pewność powtórzenia oferowana w kolejnych odsłonach cyklu oferuje stały punkt odniesienia dla tych, którzy przyzwyczajeni są do ciągłego dezaktualizowania treści w kulturze popularnej. Tymczasem moda na tego akurat bohatera nie mija, dotyczy kolejnych pokoleń odbiorców, staje się elementem kanonu, a więc i tradycji ${ }^{4}$. James Bond, będąc agentem do zadań specjalnych, legitymującym się licencją na zabijanie, działa zgodnie z regułami gatunku kryminału lub, jak kto woli, powieści sensacyjnej. Zawsze prowadzi śledztwo, wciela się więc w gatunkową rolę detektywa, który pyta,

${ }^{2}$ W.J. Burszta, M. Czubaj, Krwawa setka. 100 najważniejszych powieści kryminalnych, Warszawa 2007, s. 16.

${ }^{3}$ Bartłomiej Paszylk w kontekście gatunku filmowego superhero movie i na przykładzie filmu Superman stwierdza: „Efekt był piorunujący: wielbiciele komiksów o Supermanie nie mogli uwierzyć, że oto wyrósł przed ich oczami - i to właśnie taki, jakiego sobie wyobrażali. Z kolei wielbiciele kina niezainteresowani komiksami przyznali zgodnie, że z tak ekscytującym kinem rozrywkowym nie mieli dotąd do czynienia”. B. Paszylk, Superhero movie, [w:] tegoż, Słownik gatunków i zjawisk filmowych, Warszawa-Bielsko-Biała 2010, s. 246. O poszerzeniu pola znaczeniowego komiksu poprzez różnego rodzaju działania upowszechniające związane z promocją filmów bardzo interesująco pisze Tomasz Żaglewski. Zob. T. Żaglewski, Kinowe uniwersum superbohaterów. Analiza wspótczesnego filmu komiksowego, Warszawa 2017.

${ }^{4}$ Por. Nöell Carroll nie ukrywa, że powtórzenie jest elementem niezwykle istotnym $\mathrm{w}$ kontekście definiowania popkultury: „Upodobanie do sztuki łatwo dostępnej tak szybko nie zginie, ani też przyjemność, jaka płynie ze wspólnego doświadczania tych samych dzieł sztuki z wieloma współobywatelami. Ludzie lubią mieć kontakt z tymi samymi dziełami sztuki, co sąsiedzi. Jest to element zjawiska, które Kant nazwał «socjalizującą rolą sztuki». Lubimy czytać, oglądać, słuchać tych samych rzeczy, a następnie o nich rozmawiać. Jest dla nas ważne, że nasi kochankowie i współpracownicy dorastali przy tych samych piosenkach i programach telewizyjnych, co my. To ważny składnik wspólnoty kulturowej”. N. Carroll, Filozofia sztuki masowej, przeł. M. Przylipiak, Gdańsk 2011, s. 23. W tym wypadku powtórzenie jest wpisane nie tylko w schemat przeżyć głównego bohatera, ale w samą konstrukcję postaci, którą można określić mianem superbohatera. 
szuka, dociera do miejsc, w których jego obecność jest niewygodna. Jednocześnie aktywnie reaguje na rzeczywistość, swoje nieprzeciętne umiejętności wykorzystując do obrony świata przed złem. Wspomniane zdolności czynią go superbohaterem. Bond wykorzystuje również do pokonania przeciwnika osiągnięcia najnowszej technologii oraz inteligencję. Jego działania mogą więc być podstawą do mówienia o komiksowości postaci oraz posiadaniu cech superbohaterskich ${ }^{5}$.

Nieprzeciętne zdolności to nie jedyna cecha łącząca detektywów prowadzących śledztwa i superbohaterów. Poświęcenie się walce ze złem często bywa konsekwencją traumatycznych przeżyć z dzieciństwa lub młodości. Niełatwa przeszłość oraz determinujący teraźniejszość wybór w dorosłym życiu powoduje, iż detektywi oraz superbohaterowie żyją w specyficznym rozdwojeniu między zwyczajnością a nadzwyczajnością, codziennością i niesamowitością, spokojem i wielkim napięciem. W przypadku superbohatera moment wypełniania obowiązków wobec miasta, kraju, świata czy po prostu społeczeństwa rozpoczyna się poprzez przemianę - zwykły mężczyzna (bo zazwyczaj jest to przedstawiciel właśnie tej płci) staje się kimś, kto zwraca uwagę swoją posturą, emanującą od niego siłą, strojem zapowiadającym nadejście tego, co nieuchronne. O ile u superbohaterów ten strój w sposób dosłowny ukierunkowuje na wspomniane wcześniej rozdwojenie tożsamościowe, o tyle u detektywów czy detektywek wchodzenie w rolę osoby ratującej przed złem odbywa się w sposób nieco bardziej zniuansowany. Bywa zapowiadany przez przygotowania dotyczące wyglądu zewnętrznego. Warto w tym kontekście przywołać opis Lisbeth Salander z powieści Stiega Larssona, która wybiera się na kluczową dla jej dalszych losów oraz oceny jej przeszłości rozprawę sądową. Ale istotny jest również deklarowany zamysł autora, który nie ukrywa, że w rozmyślaniu o postaci hakerki ważną rolę odegrała kwestia przemiany:

Starałem się iść pod prąd, w porównaniu ze zwykłymi powieściami kryminalnymi. Chciałem stworzyć bohaterów, którzy różnią się znacznie od zwykłych postaci z kryminałów. Moim punktem wyjścia stała się właśnie Pippi, która byłaby już dorosła. Nazwano by ją socjopatką, bo patrzy na społeczeństwo w inny sposób, nie próbuje przystosować się do norm społecznych? Przekształciła się więc w Lisbeth Salander, która ma też sporo cech męskich ${ }^{6}$.

Irene Lind widzi zależność między sposobem konstruowania postaci hakerki a wizerunkami kobiet w komiksach:

Jest nie tylko pierwszą hakerką-detektywem, ale również pierwszą prawdziwą kobietą czynu, niemającą odpowiednika we wcześniejszej literaturze. Tak wysoki poziom kobiecej agresywności można było spotkać do tej pory jedynie u bohaterek filmów i komiksów, jednak zwykle ukrywały się one pod sugestywnymi kształtami kobiety-Kota czy Lary Croft ${ }^{7}$.

Barbara Limanowska również kładzie nacisk na komiksowy charakter oraz niejednoznaczność tożsamościową bohaterki Larssona. Jest zdania, że skojarzenia z mocnymi, silnymi postaciami kobiet-superbohaterek wykreowanych przez popkulturę pojawiają się nieprzypadkowo:

${ }^{5}$ Zob. M. Grzesiek, James Bond. Szpieg, którego kochamy. Kulisy najdłuższego serialu w dziejach kina, Warszawa 2011.

${ }^{6}$ Cyt. za: D. Jakobsen, Lisbeth Salander alias Pippi Långstrumpf, przeł. R. Chojnacki, „Deckare.pl”,

<http://kryminal.ubf.pl/readarticle.php?article_id=270> (dostęp: 5.05.2010).

${ }^{7}$ I. Lind, Tajemny klucz do Millenium skandalisty Stiega Larssona, przeł. K. Jachimska-Małkiewicz, Gliwice 2010, s. 126. 
Pierwowzoru Salander również można doszukiwać się w postaciach z powieści przygodowej. Ale w jej przypadku nie są już one tak oczywiste [jak w przypadku bohatera-mężczyzny - przyp. B.D.]. Można szukać podobieństwa z hrabią Monte Christo, ale również z bohaterami sagi o wampirach Anne Rice, bohaterką filmu Kill Bill Tarantina, i z postaciami z komiksów i gier komputerowych Salander to Kobieta Kot i Lara Croft z komputerowym umysłem. Salander wyłamuje się też z ram konwencjonalnej bohaterki kryminału, jako że Larsson szczodrze nadaje jej cechy „męskie”, ofiarowując władzę (pieniądze) i silną rękę (dosłownie), a odbiera cechy kobiece - empatię, niezdecydowanie, emocjonalność. Salander zakochana jest w Blomkviście, a zarazem zainteresowana lesbijskim seksem. To hybryda męskich i kobiecych cech i fantazji, którą łatwo odnaleźć w feministycznej, szczególnie lesbijskiej, literaturze detektywistycznej i science fiction ${ }^{8}$.

Równie ciekawe pod względem zaistnienia przemiany jest zachowanie Kathy Mallory z serii kryminalnej Carol O’Connell. Bohaterka opisana zostaje następująco:

Paliła się tylko jedna latarnia. W kręgu światła stała samotna postać w wysokich butach i długim czarnym płaszczu. Jej twarz ocieniało szerokie rondo czarnego kapelusza ${ }^{9}$

i dalej:

Wszyscy gapili się na ciemną ulicę, na której paliła się tylko jedna latarnia. Po chwili zgasła. Zapaliła się inna latarnia bliżej tłumu i pod nią znów pojawiła się Mallory. I tak ukazywała się i znikała w ciemności, zbliżając się do ludzi. Wreszcie zapaliła się ostatnia latarnia u wylotu ulicy, ale tym razem krąg światła był pusty. Mimo to tłum wpatrywał się w jasną plamę, czekając na czarną postać. [...] Mallory wynurzyła się z ciżby, stając na krawędzi półkola zbrojnych w kamienie napastników. Mężczyźni stojący najbliżej cofnęli się, kiedy uniosła poły płaszcza, ukazując spoczywający na udzie rewolwer ${ }^{10}$.

Obie przywołane bohaterki mają za sobą trudną przeszłość, traumatyczne doświadczenia z dzieciństwa, doświadczenie odrzucenia. To, co minęło, upomina się o swoje w dorosłym życiu. Bohaterki muszą wziąć sprawy w swoje ręce. Nie pozwalają na to, by przeszłość została zapomniana, zwłaszcza że pewne rachunki dopiero muszą zostać wyrównane. W walce między dobrem a złem czas tylko pozornie bywa sprzymierzeńcem przestępców. Ofiary nie poddają się sile przemijania i stają się osobami aktywnie upominającymi się o pamięć o tym, co powinno zostać napiętnowane. Taka postawa łączy osoby prowadzące śledztwo w powieści kryminalnej z superbohaterami z komiksów.

Obserwowanie życia prywatnego detektywek i detektywów pozwala stwierdzić, iż zaangażowanie w walkę ze złem zazwyczaj negatywnie wpływa na relacje z bliskim oraz na celebrowanie codzienności w zaciszu domowym. Sytuacja kobiet zostaje zwykle zarysowana jako dużo bardziej konfliktowa. Fakt, iż poświęcają się one pracy, rezygnując z czynnego uprawiania stereotypowych ról żony i matki, skutkuje zwykle rozstaniem z partnerem, a czasami ograniczeniem relacji z dziećmi. Nie inaczej wyglądają życiowe komplikacje mężczyzn. Oni również z racji wykonywanego zawodu rzadko bywają w domu, nie można na nich polegać, bo ich dyspozycyjność

${ }^{8}$ B. Limanowska, Mężczyzna, który pisał feministyczne kryminały, „Pogranicza” 2009, nr 6, s. 94-95.

${ }^{9}$ C. O’Connell, Lot kamiennego anioła, przeł. Ł. Praski, Warszawa 1999, s. 364.

${ }^{10}$ Tamże, s. 368. 
nie dotyczy rodziny, ale pracy, często popadają w różnego rodzaju uzależnienia, zdarza się też, że mają kłopoty zdrowotne. Próba ratowania świata przed złem kończy się więc często niemożnością uratowania siebie przed samotnością, porzuceniem, stygmatyzacją związaną z byciem kimś, kto w chwilach trudnych zawodzi najbliższych. Powyższe uwikłania to właściwie reguła w literaturze kryminalnej. Przykładem celnego i zniuansowanego sportretowania owych komplikacji mogą być losy policjanta Kurta Wallandera, bohatera kryminalnej serii Henninga Mankella, czy perypetie dziennikarki Anniki Bengtzon, której losy poznajemy w książkach autorstwa Lizy Marklund. Ci zwykli w gruncie rzeczy ludzie, wtedy gdy zaczynają walczyć ze złem, stają się superbohaterami. Nie zyskują nadludzkiej siły w sposób dosłowny, ale metaforycznie można by uznać, iż zachodzi w nich za każdym razem ten sam proces, który pozwala Supermanowi, Barmanowi czy Iron Manowi ruszyć na ratunek całemu społeczeństwu lub jego konkretnym przedstawicielom. Powtarzalność owej przemiany wydaje się znacząca, zwłaszcza że wpisana ona zostaje w walkę dobra ze złem. Zasadne staje się stwierdzenie, iż uczestniczenie w wojnie z mroczną stroną istnienia wiąże się z koniecznością włożenia maski i kostiumu, dzięki którym zyskuje się więcej symbolicznej siły. Możliwość przeżywania podobnych dylematów i emocji, jaka jest udziałem superbohaterów, powoduje, iż detektywi niejednokrotnie doświadczają izolacji, skazującej ich na funkcjonowanie w ciągłym zawieszeniu. Doświadczenia walki ze złem są na tyle intensywne, że nie da się ich zostawić w pracy i w domu o nich nie myśleć. Ciągłość i nieustanność procesu myślenia związanego ze śledztwem prowadzi do wykluczenia z codzienności znaczonej typowymi zajęciami związanymi z życiem rodzinnym.

W efekcie detektywka czy detektyw, podobnie jak superbohaterowie, mierzą się na co dzień z sytuacją, która nie pozwala im na bycie częścią grupy, z którą się utożsamiają. Pracując, w pewnym sensie wyrzekają się prywatności, próbując zintensyfikować relacje $z$ bliskimi, trwają w oszustwie, bo nie potrafią zaangażować się w pełni w bycie ojcem i partnerem, myślą bowiem cały czas o zobowiązaniach zawodowych. Wspominałam wcześniej o połączeniu cech bohatera powieści kryminalnej z cechami superbohatera w przypadku agenta 007. Kurt Wallander, który w sensie ideowym może być postrzegany jako odpowiednik superbohatera à rebours, przez Wojciecha J. Bursztę i Mariusza Czubaja zostaje nazwany antybohaterem:

[...] to właściwie antybohater. Zgorzkniały mężczyzna po czterdziestce, któremu ciągle dolega, a to ból brzucha, a to katar, z rozbitym życiem osobistym, niepotrafiący się dogadać ani z córką, ani z ojcem malującym niezmiennie ten sam pejzaż. Nudny policjant zwołujący zebrania swojego zespołu i czekający na przełom w śledztwie. I może ze względu na tę przeciętność postaci dziennikarze dzwonią do Henninga Mankella z pytaniami, jak głosowałby Wallander w najbliższych wyborach ${ }^{11}$.

Stwierdzenie badaczy nie tylko stawia bohatera powieści w innym świetle poprzez zaakcentowanie jego negatywnych cech. Stanowi również interesujący pretekst do zastanowienia się, czy faktycznie superbohatera i antybohatera tak wiele dzieli. Okazuje się bowiem, że pojawia się całkiem realna możliwość interpretowania określonych zachowań w sposób pozytywny lub co najmniej wyrozumiale, ale i negatywny jednocześnie. W zależności od tego, jakiej oceny dokonamy, postać może być rozpatrywana jako antybohater lub superbohater. Osamotnienie jednego i drugiego jest niewątpliwe. Zdarza się, że nie różni ich również etyczne uwikłanie

${ }^{11}$ W.J. Burszta, M. Czubaj, Krwawa setka..., s. 17. 
czynów. Superbohater bywa także stawiany w sytuacjach wymagających od niego podjęcia decyzji, które potocznie zakwalifikowalibyśmy jako tzw. mniejsze zło. Większa jest natomiast u niego świadomość moralnej odpowiedzialności za to, co robi nawet pod przymusem. Być może niekoniecznie najbardziej celne jest wspominanie w tym akurat kontekście o antybohaterze. Superbohater, choć ratuje świat, może być niezbyt dobrym towarzyszem w życiu prywatnym. W efekcie, jeśli przyjrzymy się jego codzienności i dostrzeżemy obecną w niej konieczność ukrywania ważnej części siebie, kłamstwo będzie elementem stałym tego kogoś, kto symbolicznie lub dosłownie zmienia się, by poddać się przymusowi odpowiedzialności za społeczeństwo. Nie tak łatwo byłoby obronić tezę, że chodzi o relatywizm moralny tak typowy dla antybohaterów. Na plan pierwszy wysuwają się raczej konsekwencje podejmowanych błędnych decyzji oraz wyrzekanie się pewnego porządku etycznego w kontekście prywatności na rzecz poświęcenia się temu, co wiąże się z dobrem wspólnym i bezpieczeństwem zbiorowości. Nie da się też nie dostrzegać zwyczajności, w jaką uwikłany jest bohater. Staje się ona wyznacznikiem jego rzeczywistości, ale jednocześnie za sprawą pełnionej roli społecznej i podejmowanej samotnej walki ze złem zyskuje nowe oblicze. Okazuje się częścią tego, co tworzy tło dla obudzenia się, ujawniania się i następnie ponownego uśpienia superbohatera.

Przyglądanie się detektywkom i detektywom prowadzącym śledztwa w powieściach kryminalnych pod kątem podobieństwa do superbohaterów nie stanowi bynajmniej próby ich uwznioślenia. Bardziej zasadne staje się interpretowanie tego gestu w kontekście wzajemnego dialogowania różnych tekstów kultury oraz swobodnego przepływu schematów charakterologicznych i zachowań w kulturze popularnej. To, co w przypadku superbohaterów kojarzy się z nadludzkimi umiejętnościami, w działaniach pierwszoplanowych postaci w kryminałach objawia się podobnymi cechami, tyle że wpisanymi w zwyczajność i niesygnalizowanym rozpoznawalnym strojem. Gotowość ratowania świata przed złem okazuje się spoiwem, dzięki któremu wspólnota ideowa wysuwa się na pozycje dominujące, unieważniając różnice związane ze sposobem kreowania postaci i wpisaną w niego umownością. Kulturowo postać superbohatera jest ucieleśnieniem marzenia o istnieniu godnego przeciwnika tych, którzy stoją po stronie zła. Detektyw, zrzucający maskę i/lub strój będący znakiem rozpoznawczym superbohatera, pozostaje osobą stojącą po tej samej stronie barykady co jego komiksowy odpowiednik. Mówiąc kolokwialnie, grają w jednej drużynie, choć wkładają metaforyczną zbroję, kiedy szykują się do kolejnej bitwy, ujawniają odmienne gusta. Detektyw kamufluje się i nie chce być w trakcie śledztwa od razu zidentyfikowany, superbohater, gdy podejmuje interwencję, jest rozpoznawalny i widoczny dzięki kostiumowi, który go, tak można powiedzieć, stwarza. Zarówno w życiu detektywa, jak i superbohatera, ważna staje się umiejętność właściwego rozpoznania, kiedy należy skryć się za tym, co typowe i przeciętne, a kiedy trzeba wyeksponować taki swój wizerunek, który ma w sobie coś niezwykłego. Niezależnie jednak od tkwiącego w nich potencjału identyfikacji wizualnej, wspólny cel każe rozpatrywać obie postaci poprzez podobieństwa, a nie różnice. 


\title{
SŁOWA KLUCZOWE:
}

a $n$ t y b h a t e r

powieść kryminalna

\begin{abstract}
Abstrakt:
W artykule zwrócono szczególną uwagę na detektywa jako postać kluczową dla opowieści o walce ze złem. Zachowania detektywa, jego decyzje i sposób myślenia pozwalają na zderzenie tej postaci $z$ komiksowym superbohaterem. Przedstawiono podobieństwa między detektywem a superbohaterem, kładąc nacisk na symbolikę maski oraz stroju wkładanego dosłownie lub metaforycznie wtedy, gdy dochodzi do starcia z tymi, którzy stoją po stronie zła. Jednocześnie zwrócono uwagę na niejednoznaczność zwyczajności i słabości stanowiących część charakterystyki współczesnego detektywa, pozwala ona bowiem na rozpatrywanie bohatera kryminału w kontekście antybohatera, który - nieco paradoksalnie - jednocześnie wciela się w rolę superbohatera.
\end{abstract}




\section{detektyw}

\section{NOTA O AUTORZE:}

Bernadetta Darska - ur. w 1978 r. Krytyczka literacka. Doktor habilitowana literaturoznawstwa. Pracuje w Instytucie Dziennikarstwa i Komunikacji Społecznej UWM. Wykładowczyni w Szkole Mistrzów Pióra w Collegium Civitas. W latach 2002-2009 redaktor naczelna pisma literacko-kulturalnego „Portret”. Autorka dziewięciu książek. Ostatnio opublikowała Pamięć codzienności, codzienność pamiętania. Szkice o reportażu polskim XXI wieku (2014), Maski zła. (Nie)etyczność postaw i zachowań jako temat wspótczesnego reportażu polskiego (2016) oraz Młodzi i fakty. Notatki o reportażach roczników osiemdziesiatych (2017). Od 2009 roku przez sześć lat prowadziła blog krytycznoliteracki: „A to książka właśnie!”, teraz zaprasza na "Nowości książkowe”: www. bernadettadarska.blogspot.com 